Portland State University

PDXScholar

7-23-1973

\title{
A Comparison of Two Methods of Instruction in Office Skills: Classroom-Laboratory and Classroom- Laboratory with Cooperative Work Experience
}

Barbara Swanson Anderson

Portland State University

Follow this and additional works at: https://pdxscholar.library.pdx.edu/open_access_etds

Part of the Educational Assessment, Evaluation, and Research Commons, and the Educational Methods Commons

Let us know how access to this document benefits you.

\section{Recommended Citation}

Anderson, Barbara Swanson, "A Comparison of Two Methods of Instruction in Office Skills: ClassroomLaboratory and Classroom-Laboratory with Cooperative Work Experience" (1973). Dissertations and Theses. Paper 2182.

https://doi.org/10.15760/etd.2179

This Thesis is brought to you for free and open access. It has been accepted for inclusion in Dissertations and Theses by an authorized administrator of PDXScholar. Please contact us if we can make this document more accessible: pdxscholar@pdx.edu. 
AN ABSTRACT OF THE THESIS OF Barbara Swanson Anderson for the Master of Science presented August, 1973.

Title: A Comparison of Two Methods of Instruction in Office Skills: Classroom-Laboratory and ClassroomLaboratory With Cooperative Work Experience APPROVED BY MEMBERS OF THE THESIS COMMITTEE:

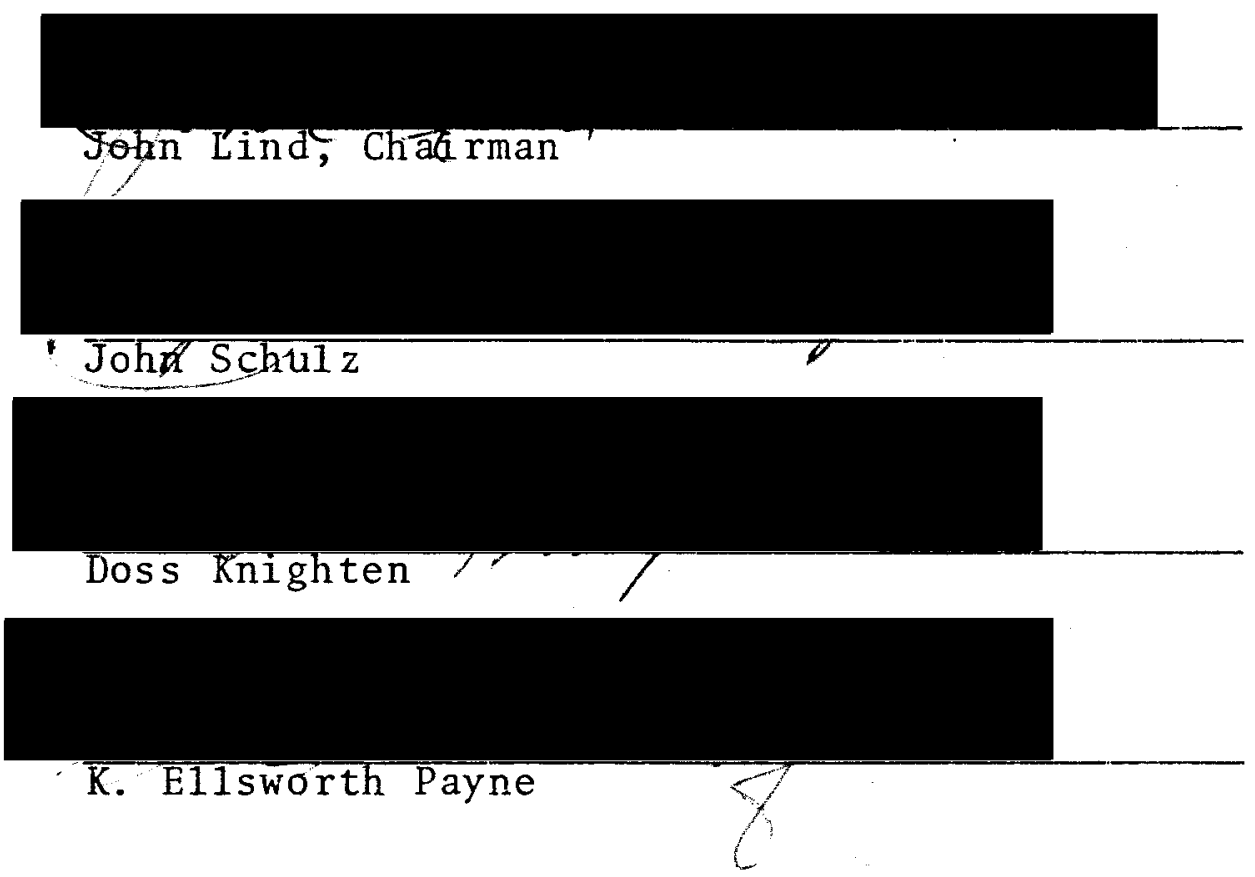

This research study is designed to take an initial step in the direction of determining whether cooperative office education programs are more effective in teaching clerical skills, in preparing students for office employment, and in helping them to achieve employment and job success than classroom-laboratory training in office skills alone. Two groups totaling 35 students were compared. One group obtained 
classroom-laboratory training in office skills alone while the other received the same classroom-laboratory training plus several hours per week of work-experience in office situations. It was found that there were no significant differences between groups on initial measures of vocational interest, school motivation, intelligence, grade point, and business course background. There were also no significant differences between groups on pre-tests: Office Information and Skills, Minnesota Clerical, and Short Tests of Clerical Ability. There"were no significant differences between groups on post-tẹts of Office Information and Skills, lettertyping skill, Short Tests of Clerical Ability, Business Judgment, and employee and employer satisfaction. There was a statistically significant difference in favor of the Cooperative group on the Minnesota Clerical i'est. There was a large difference between Office Practice and Cooperative Students in employment status. Cooperative students showed a much higher percentage of employment as well as of employment in clerical and office situations. It is noted that this difference may be attributable to complex factors arising from the increased attention received by the Cooperative Students. It is concluded that, although the study had limitations, there are a number of factors identified which support continuation of Cooperative Business Education programs, as well as a number indicating a need for further research to determine relative effectiveness of Cooperative and $\mathrm{Classroom-1aboratory} \mathrm{programs} \mathrm{in} \mathrm{office} \mathrm{skill} \mathrm{training.}$ 
A COMPARISON OF TWO METHODS OF INSTRUCTION IN OFFICE SKILLS: CLASSROOM-LABORATORY AND CLASSROOM-LABORATORY WITH COOPERATIVE WORK EXPERIENCE

by

BARBARA SWANSON ANDERSON **

A thesis submitted in partial fulfillment of the requirements for the degree of

\author{
MASTER OF SCIENCE \\ in \\ EDUCATION
}

Portland State University

1973 
TO THE OFFICE OF GRADUATE STUDIES AND RESEARCH:

The members of the Committee approve the thesis of Barbara Swanson Anderson presented July 23, 1973

John Lind, Chairman

Johnschulz

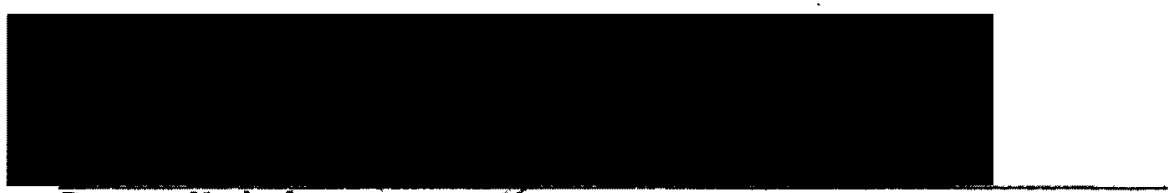

Doss Knighten

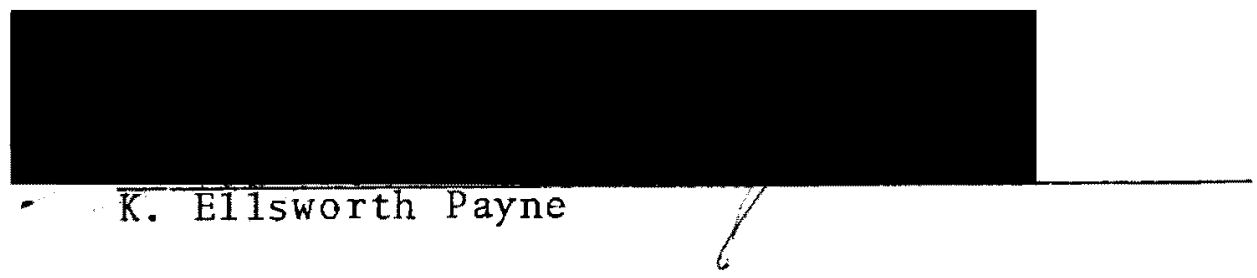

APPROVED :

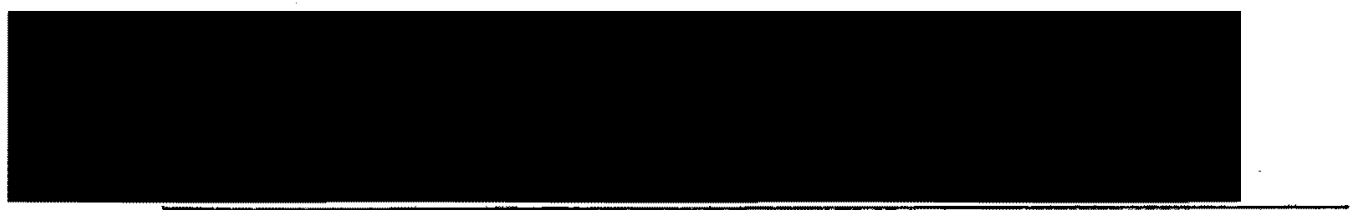

William A. Jenkins, Dean of the School of Education

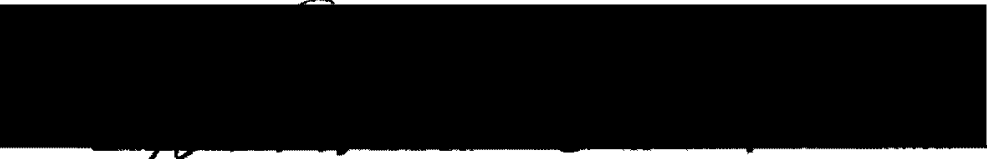

David T: Clark, Dean of Graduate Studies and Research July 26,1973 
TABLE OF CONTENTS

PAGE

PREFACE . . . . . . . . . . . . . . . . . iv

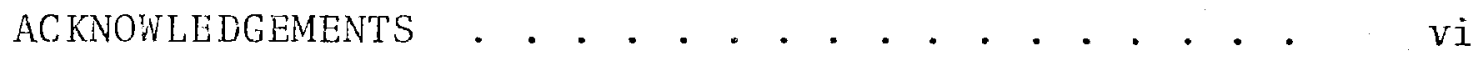
LIST OF TABLES . . . . . . . . . . . . . . . . viii CHAPTER

I PURPOSE OF THE STUDY . . . . . . . . . . . 1

I I REVIEW OF THE LiteRATURE . . . . . . . . . 3

II I DEFINITION OF TERMS

IV METHODS OF STUDY . . . . . . . . . . . . . 11

Scope . . . . . . . . . . . . . . . . 11

Hypotheses . . . . . . . . . . . . 14

Data Collection . . . . . . . . 16

Instruments and Measures. . . . . . 19

Statistical Data Analysis . . . . . 26

$\mathrm{V}$ ANALYSIS OF FINDINGS . . . . . . . . . . . 30

Comparative Data... . . . . 30

Summary of Major Findings . . . . 38

VT CONCLUSIONS AND RECOMMENDATIONS • . . . 39

REFERENCES . . . . . . . . . . . . . . 48

BIBLIOGRAPHY . . . . . . . . . . . . 52

APPENDIX . . . . . . . . . . . . . . . 53 


\section{PREFACE}

Development of vocational education programs was spurred by the passage of the Smith-Hughes Act in 1917, and such programs are now increasingly accepted as necessary for al1 school districts and important for many individual students. Types of prograins developed are numerous, including the classroom-1aboratory in which young people are taught both practical skilis and related knowledge prior to employment, and the cooperative work experience program in which skills and knowledge are taught in the classroomlaboratory also, but are suplemented by an opportunity to learn and earn in a part-time work situation.

In 1962 , a panel on vocational education was convened by President Kennedy and later reported that many vocational graduates were not adequately prepared for their occupations. In its final report, the panel emphasized that "..education for occupational competency be carefully correlated with the possibility for employment."l It seens that a program in which students have actual on-the-job experience could provide both the more adequate preparation and also, perhaps, that greater likelihood of employment in the field of training recommended by the President's panel.

Although classroom-1aboratory and/or cooperative programs are found in many communities, and are designed to 
prepare students for employment upon completion of the course work, there is 1ittle information on their relative effectiveness.

The project discussed in this paper was designed to take an initial step in the direction of determining whether cooperative office education programs are more effective in teaching clerical skil1s, in preparing students for office employment, and in helping them to achieve employment and job success than classroon-1aboratory training in office skills alone. 


\section{ACKNOWLEDGEMENTS}

I wish to express my sincere thanks to the many individuals who have assisted in the preparation of this manuscript and in the process of obtaining the necessary data. To the employers and students who so graciously gave their time and attention to the numerous tests and measures used, I wish to offer both hearty thanks and wishes for their continued success in the business world and in life. I am indebted to the members of the staff at portland state University who have given generously of their time to help and advise me. Without that help, I am sure it would have been only too easy to give up.

I also wish to thank the Vancouver School District and the Coordinating Council for Occupational Education of the State of Washington for underwriting a substantial part of the cost of this research. Janes L. Brooks, Supervisor of Occupational Fducation for Vancouver Schools, George P. Pilant, Director of Research for the state Coordinating Council and Larry Smith, Principal, have been extremely helpful and cooperative.

Finally, this thesis could not have been written without the help of all the members of my family: I am especially grateful to Dan Pass and Joyce Adams for their he1p and support; to Darlene Disbrow for the countless hours 
spent typing and working beside me, and to my daughter Lynn Webber and my husband Jim for not only help and encouragement, but for their cheerfulness about the sacrifices of time this research entailed.

These acknowledgements cannot be considered complete without mention of my typist, Carole Van Arsdol, who proved so helpful and steadfast under pressure. 


\section{LIST OF TABLES}

TABLE

PAGE

I Comparison of Results on Measures Used to Determine the Initial Equivalency of the Two Groups . . . . . . . . . . .

I Comparison of Results on Clerical Skills Test Used for Pre- and Post-testing..

III Comparison of Results on Final Measures

Used to Test Business Judgment and to Determine the Extent of Employer and Employee Satisfaction . . . . . . .

IV A Comparison of the Employment Status of the Cooperative and Office Practice Groups, June, 1973 . . . . . . . . 


\section{CHAPTER I}

PURPOSE OF THE STUDY

The purpose of this study was to analyse, evaluate and compare the relative effectiveness of cooperative and classroom-1aboratory training in business and office education. Two elective prograns at Hudson's Bay High School in Vancouver, Washington were compared. In one program, seniors elect two hours of daily classroom-laboratory training in Office Practice. In the other, seniors elect the same two hours of classroom-1aboratory training while they also vo1unteer for the Cooperative Business Education Program in which they work approximately fifteen hours per week, for wages, in a business office situation. For convenience, this study will refer to these two groups as "Cooperative Students" and "Office Practice Students." The study is designed to determine which group obtains the rnore adequate preparation for future employment and which achieves greater job success and satisfaction:

More specifically the study sought answers to the following questions:

1. Do Cooperative Students obtain significantly different scores than office Practice Students on pre-test measures of vocational interest, c1erical skills, school motivation, and intelligence quotient? 
2. Do Cooperative Students differ significantly from office Practice students on measures of grade point average, and number of business courses taken?

3. Do Cooperative Students obtain significantly higher scores than Office Practice Students on post-test measures of clerical skills and business judgment?

4. Do Cooperative Students, approximately one month after graduation, show a higher percentage of employment and of employment in office situations than do the Office Practice Students? 


\section{CHAPTER I I}

\section{REVIEW OF THE LITERATURE}

A study of the various sources of information on published studies, with special concentration on ERIC ${ }^{2}$ and $\mathrm{ARM}^{3}$ revealed that there has been 1ittle research on the effectiveness of Cooperative Education Programs in any area of vocational instruction. Further, no published studies on the effectiveness of Cooperative Programs in business and office education were found. The following is a brief summary of the existing relaced research. An Army ${ }^{4}$ study, pub1ished in 1970, considered the effectiveness of a cooperative program at the college leve1 in helping to assure maximum retention of students as employees upon graduation. There was no attempt in this study to compare the cooperative method of instruction to other methods. The focus instead was to evaluate the cooperative progran then in existence at the Redstone Missile Command station. The study concluded that efforts needed to be made to make the cooperative program more relevant to student course work and goals. It a 1 so determined that, although twenty-eight students indicated they were planning to return to their work situation, thirty-seven others probably would not, thus indicating that the program apparently failed in its goal of 
encouraging the students to remain as employees after graduation. A majority of students did, however, express satisfaction with the cooperative program.

LaVerne Ryan (1969) 5 , compared cooperative to simulated methods for teaching office skills. Although this study is not yet available through the ERIC microfiche service, the abstract indicates that the conclusions of the study were that the cooperative method is more effective, although simulation is appropriate where a cooperative program is not feasible. Again in this study, there is no comparison of cooperative to classroom-1aboratory office programs.

Ferguson (1969) 6 , compared "project" and cooperative methods in distributive education, "project" being an individualized learning package approach. His results indicated that there was no significant correlation between the variables of socio-economic status, age, sex and teachers" attitudes and the scores students attain on tests of sales and economic understanding, that there was a positive correlation between students' prior achievement and certain test scores; that the cooperative classes scored significantly higher on sales comprehension than project classes but not significantiy different on tests of economic understanding.

Miller $(1968)^{7}$, studied the holding power of dropouts placed in "work-experience" (or cooperative) programs in which they worked in the school building. Miller found no significant difference to show that the cooperative progran 
contributed to keeping the potential dropouts in school. Nor did he find significant differences indicating that the cooperative program increased school activity participation or decreased discipline problems, or raised grade point or attendance. He did find that, in some schools, certain of these factors did show a significant improvement, but that this was not consistent from school to school. He did speulate that placement of the students in a business, rather than a school setting, for the work experience might have proved more effective.

Hodge $(1968)^{8}$, investigated the role of cooperative office education in the development of favorable attitudes toward office work during a period of one semester. Using a pre- and post-test design to measure attitude toward office employment, he found there was no significant difference in attitudes toward office work between the cooperative and non-cooperative office education students on either the pre-test or the post-test.

In 1970 , Rothwel1 and Baker ${ }^{9}$ studied the relationship of personality factors and clerical pre-tests to later job success. The summary concluded that the "National Business Entrance Stenographic Test" and four personality traits Cintelligence, emotional stability, tender-minded and shyventuresome) from the "16 P.F. Personality Test" are predictors of job success when this success is measured using the "Minnesota Satisfactoriness Scales." A careful reading of the data in this study do reveal a contradiction, 
however, Although the summary indicates that shy-venturesomeness was the most significant predictive factor, the body of the document states that the null hypotheses for that factor was accepted since the coefficient of correlation of -0.029 for shy-venturesome did not exceed the critical value of \pm .1946 . In other words, shy-venturesomeness was not a significant predictive factor. An error so serious calls into question the validity of other elements of the study.

Lee $(1966)^{10}$, studied cooperative education programs to determine the extent to which such programs serve the needs of low-average ability students. Her data was obtained largely from coordinators of such programs and indicated that most of their low ability students did benefit, although only a limited number were enrolled in cooperative office prograns.

Lewis (1966) ${ }^{11}$, conducted a study in the mid-west surveying cooperative education coordinators. Her findings were related to the nature and requirements of programs offered and to the problems encountered. The problems most frequently mentioned by coordinators were: scheduling, selecting competent trainees, lack of time, lack of training stations, and inadequate school facilities.

Shultz (1957-58) 12 , surveyed cooperative programs in Pennsylvania. He concluded that, al though coordinators in cooperative programs tend to do an inadequate job because of limitations of time and funds, the programs were good 
in promoting student morale and self-confidence.

The Cook and Lanham ${ }^{3}$ study of 1966 in Detroit did provide some statistical data on cooperative work study. They found that a significantly higher percentage (at the .02 level of confidence) of cooperative students had held entry level jobs than all other graduates. Retention of jobs, however, was not significantly different.

Lester Sanders'14. study (1967), "A Comparison of Two Methods of Preparing Youth for Employment: Cooperative Occupational Education Versus the Preparatory Vocationa1Technical School" is the most applicable, of a1l the research reviewed, to the problem and purpose of this study. It compares, by means of records and surveys, the attitudes of students, their extra-curricular activities, training beyond high school, prior background, employment status, parent and employer attitudes, and relative costs for both types of programs.

The following are the several conclusions reached by Sanders as a result of his study. Vocational programs are more effective in maintaining student interest and improving attitudes. Cooperative graduates emphasized development of personal-social skills while vocational graduates emphasized job skills and knowledge. Transition from school to full employment is faster and easier through cooperative programs. Most vocational students do work in unsupervised situations in high school. Vocational graduates, after an adjustment period, do tend to return to 
the occupations for which they trained in greater numbers than cooperative graduates. Cooperative graduates tend to demonstrate more desirable personality traits, work habits, and a higher degree of occupational competency.

Sanders" study deals with students involved in "trade" instruction (food trades, health, mechanics, construction, etc.) and does not include any students training for office occupations. Thus, although his study, more than any others reviewed, does make some clear comparisons of cooperative versus vocational classroom-laboratory training, it gives no comparisons of training methods in office skills. In addition, some of Sanders' conclusions are based to a considerable extent on relatively subjective types of information. As this review of the literature indicates, although a number of papers have been written about cooperative education, there are very few research studies in which an objective effort has been made to compare cooperative to other common methods of vocational instruction, and apparently none which compare cooperative and classroomlaboratory instructional methods in office skills. Thus, although it is often assumed that cooperative business education has many advantages over the more usual class-room laboratory courses in "Office Practice", there is little concrete evidence to prove this assumption. Even though complex variables make such a study difficult, an effort should be made to at least tentatively cither support or reject these assumptions. 


\section{CHAPTER III}

\section{DEFINITION OF TERMS}

There are a number of terms used throughout this paper which may require some clarification. Although, throughout the country, cooperative work-experience and "Office Practice" programs are designated by a wide variety of titles, an effort has been made in this paper to be consistent in the use of terms.

COOPERATIVE BUSINESS EDUCATION refers to a progran for high school seniors enrolled in "Office Practice" who, through a cooperative arrangement between the school and the employers, receive vocational instruction in the school's classroom-laboratory and at the same time receive on-the-job training through their part-time, paid employment in a business office situation.

COOPERATIVE STUDENTS are the students at Hudson's Bay High school who volunteer for, participate in, and graduate from the Cooperative Business Education Program. OFEICE PRACTICE PROGRAM refers to the classroomlaboratory program of instruction in office practices and skills which does not include on-the-job training but does include both class instruction and laboratory skills training in the school situation. 
Office Practice Program who do not volunteer for the on-thejob training provided in the Cooperative Business Education Program.

COOPERATIVE EMPLOYERS are the businesses or institutions by which the Cooperative Students are employed during the school year.

EMPLOYERS are the businesses or institutions reported by the graduates of both the Cooperative and Office Practice Programs as their places of employment approximately one month after completing. their high school training at graduation.

It is important to be aware that Cooperative Business Education and Office Practice Program refer to two methods of instruction which are at the same time similar and different. In both programs students receive instruction in the vocational classroom-laboratory. However, only through the Cooperative Business Education program do some students also receive an opportunity to have a paid work experience in a business office in the community.

The term classroom-1aboratory is used to indicate an instructional situation in which the office trainee receives a combination of "traditional" classroom instruction plus laboratory skills training on various machines and equipment commonly used in the modern office. A11 of the students included in this study received the same classroomlaboratory training. The cooperative students also received the training of a work-experience situation. 
CHAPTER IV

\section{METHODS OF THE STUDY}

\section{SCOPE}

This study involved the Cooperative Business Education students and the Office Practice students at Hudson's Bay High School, Vancouver, Washington and their employers during the school year 1972-73, and for about one month thereafter. A total of 35 female students were the subjects of the study. All of the students were scheduled randomly by district computer into one of two two-hour blocks of c1assroom-1aboratory instruction in Office Practice. The first two-hour block contained approximately two-thirds Cooperative Students and one-third Office Practice Students. The second two-hour block contained approximately one-third Cooperative Students. Al1 students were taight by the same instructor using the same individualized materials in office skill training.

The office Practice Students consisted of seventeen students distributed, as indicated, between the two class time-blocks. The Cooperative Students consisted of 18 students distributed between the two time-blocks. These Cooperative Students all volunteered to enroll in the Cooperative Business Education Program in addition to Office 
Practice. (Cooperative Business Education cannot be taken alone.)

Office Practice Students received two high school credits for each semester of the two-hour class. Cooperative students also received two hours of credit for the two-hours of inschool instruction. However, they also received an additional one hour of credjt each semester for their off-campus work experience. The time spent in the work experience situation varied considerably from student to student, however, it averaged approximately 495 hours per student during the total school year of 36 weeks. Ten of the Cooperative students were hired by their Cooperative Employers during the month of October, primarily during the last week of that month. Four were employed in November; and the final four were hired midJanuary to the end of February. The Cooperative Students therefore averaged approximately 15-20 hours of work experience per week. For this they were paid wases ranging from $\$ 1.50$, per hour to $\$ 2.30$ per hour by their Cooperative Enployers.

The researcher served both as teacher of the office Practice classes and Coordinator of the Cooperative Program. The role of the Coordinator was to provide frequent feedback and evaluation between the employer and employee so as to obtain the most effective training situation for the student and a satisfactory employee for the cooperating business. The Coordinator also endeavored to adjust in-classroom training for the Cooperative students so that they could gain or 
improve the skills needed on the job.

The scope of this study is limited both by the relatively small number of subjects and by the limited period of time over which it was possible to gather data. More difinitive results might have been obtained had it been possible to administer all of the pre-tests at an earlier date and also if a longer period of follow-up on post graduation employment had been possible.

Although the study does test and compare variables of vocational interest, school motivation, intelligence, grade. average, and business course background to determine if significant differences in the two groups exist at the start of the study, a number of other possible variables are not dealt with. There are several reasons for this omission. First, limitations of time and funds make it nearly impossible to consider every variable which inight effect results in a study such as this. Second, it was felt that there were several of the other possible variables which it could be safely assumed would. not effect results because of the likelihood that they would be either randomly or relatively equally distributed. For example: 1) Sex--all the subjects are female, 2) Age--all subjects are high school seniors, aged 17-18,3) Race--no more than one student in either group is of a minority race, 4) Socio-economic status-all students are from the same school population which consists fairly equally of lower-middle, middle, and upper-middle class persons and these are likely to be randomly distributed among 
the two groups, 5) A11 others--these are arbitrarily assumed to be randomly distributed.

\section{HYPOTHESES}

The rejection leve1 for the null hypotheses under test was set at the .05 level of probability. The hypotheses for this investigation were:

$\mathrm{Ho}_{1}$ That there will be no significant difference between the scores of the Cooperative Students and the Office Practice Students on several measures to determine the initial eqtivalency of the groups: the Strong Vocationa1 Interest B1ank for Women (Secretarial and Office Practice scales only), the School Motivation Analysis Test, and the Otis-Lennon Mental Ability Test, grade point average, and number of business courses taken (by semester hour].

$\mathrm{Ho}_{2}$ That there will be no significant difference between the scores of the Cooperative Students and the Office Practice Students on the Office Information and Skills Test.

$\mathrm{Ho}_{3}$ That there will be no significant difference between the scores of the Cooperative Students and the Office practice Students on a timed test of letter-typing ability. 
$\mathrm{Ho}_{4}$ That there will be no significant difference between the scores of the Cooperative Students and the Office Practice Students on the Minnesota C1erical Test.

$\mathrm{Ho}_{5}$ That there will be no significant difference between the Cooperative Students and the Office Practice Students on their composite scores on the Short Tests of Clerical Ability.

$\mathrm{Ho}_{6}$ That there will be no significant difference between the post-test scores of the Cooperative students on the Business Judgement Test.

$\mathrm{Ho}_{7}$ That there will be no significant difference between the Cooperative students and the office Practice students in percentage of satisfied response to the Minnesota Satisfaction Questionnaire.

$\mathrm{Ho}_{8}$ That there will be no significant difference between the Cooperate students ard the office Practice students in percentages of satisfied (favorable) responses of their employers on the Merit Rating Series--Clerical.

Hog That there will be no significant difference between the Cooperative students and the office practice students in percentage employed in any 
position or percentage employed in clerical/ office positions.

\section{DATA COLLECTION}

A11 tests were administered by the researcher and her assistants and scored either by hand or by recognized scoring services.

The test administration schedule of the research plan called for pre-testing in September using instrunents to measure: vocational interest, school motivation, intelligence, office information, letter-typing skill, and clerical skills (two test batteries). The second step in the testing schedule was the administration, late in the school year, of the post tests: office information, letter-typing skill, and the clerical skill test batteries. The final step was a post-graduation follow-up to determine which students were employed, and to obtain from them and their employers measures of both employer and employee satisfaction.

The research plan also called for obtaining information recorded in the permanent school files on grade point average of each student prior to entering the programs, and a count by semester hour of the number of business courses taken by each student up to that time.

This plan was followed in essence, although practical problems resulted in one important difference. Although students from both groups were administered the timed test 
of letter-writing skill and the office Information and Skills Test during the first week of September, 1972, and again during the last week of May, 1973, as originally planned, it was not possible to administer the other pre-tests until midDecember, 1972. This delay was caused by problems related to obtaining approval of the project by Washington State and Vancouver School offices and with their approval the financial support necessary to purchase the standardized tests. These tests, which were finally given December 15-17, 1972 were: Strong Vocational Interest Blank for Women, School Motivation Analysis Test, Otis-Lennon Mental Ability Test, the Minnesota Clerical Test, and Short Tests of Clerical Ability. A1l other tests were given on the originally planned schedule.

Although it was unfortunate that all of the pre-tests could not have been administered in September, it is felt that the effects of this lapse were small because the training received by the two groups was very similar up to the Decomber test date. The first Cooperative Students employed were not hired until late october. Thus, ten of the cooperative students had no more than approximately six weeks work-experience when the pre-tests were given, four had only two to three weeks work-experience, and four had not yet been in a cooperative work situation at all. It is recognized that this is an important reason for caution as regards any conclusions reached despite the relatively small differences in training at the time of pre-testing, and is 
certainly a good reason for replication of the study with an improved schedule of test administration.

During the month of June, 1973, each student was contacted individually to determine whether or not she was employed. All students employed were asked to complete the Minnesota Satisfaction Questionnaire which gives an indication of the degree to which an employee is satisfied with his employment situation. At this same time all employers were contacted and asked to complete the Merit Rating Series-Clerical which measures the degree to which the employer is satisfied with an employee. These measures were taken as 1ate as possible to allow the maximum possible amount of time for graduates to find employment and to become acquainted with their work situations, and for employers to evaluate them. A large number of the Cooperative Students (15) became full-time employees of their Cooperative Employers, while others (3) found it necessary to locate other full-time employment. Most Office Practice Students were either employed or seeking full-time employment.

Data were complete for each of the 35 subjects of the study with only a few exceptions. Strong Vocational Interest Tests were not returned by the scoring service for. two of the Cooperative Students; one of seven sections of the Short Tests of Clerical Ability was lost for one Office Practice student; and one Cooperative Student was not able to take the pre-test on the Short Tests of Clerical Ability. Return on the post-employment measures of employee 
satisfaction were $94 \%$ or better for both the Cooperative and Office Practice students for the measure of employee satisfaction. Return of the rating scale by employers was $94 \%$ in the Cooperative group, $67 \%$ in the Office Practice group.

\section{INSTRUMENTS AND MEASURES}

The following instruments and measures were selected for use in the study:

(1) The Strong Vocational Interest Blank for Women. This test was originally developed by E. Strong in 1933; the 1969 revision was used. Students in both groups were compared on two scales of the test: a) Basic Interests-Office Practice, and b) Occupational--Secretary. There is extensive data in the manuals on reliability and validity for the Strong Test. "Test-retest correlations for 30 days average slightly over .90 , dropping to about .75 over 20 years for adults... W. When the SVIB is used for those below the age of 21 , the possibility of future change must be recognized."15 The Occupational Scales, although not constructed to be internally consistent, on reliability measures show correlations around .80. "The Basic Interest Scales are internally consistent..... and test-retest correlations are a few points lower than those of the occupational Scales."16 Predictive and concurrent validity for high school students is indicated by the manual to be satisfactory, "...to indicate general direction of career but not 
specific occupation."17 Extensive data on validity is given in the "Manua1."

(2) Schoo1 Motivation Test. This test was developed by Arthur Sweney, Raymond Cattel1, and Samuel Krug at the Institute for Porsonality and Ability Testing and copyrighted in 1961 and 1970. Although Buros ${ }^{18}$ indicates that there is little conclusive data available on validity and reliability for this test, the work of Sweney and Cattell on attitude is difinitive, and little else exists which is recommended by measurement experts for testing motivation.

(3) Otis Lennon Mental Ability Test. This test was designed by Arthur $S$. Otis and Roger T. Lennon and copyrighted in 1967. "The construction and norming of this test bespeaks adherence to the highest 1 evel of current standards."19 Exce1lent data on reliability and validity are given jn the "Manual for Administration."20 Corrected split-half and Kuder Richardson reliability coefficients indicate correlations of .96 and .95 respectively for the Advanced Test used for grade 12. Alternate-forms reliability coefficients give a correlation of .92. Standard error of measurement for the Advanced Test for grade 12 was 4.7 IQ points. Although the "Manual for Administration" does not give the extensive data available on validity, this information is to be made available in the "Technical Handbook." John E. Milholland, reviewing the tests in Buros 21 says, "The validity research was wide ranging and 
abundant data are provided. The test correlates adequately with educational criteria and with other measures of general scholastic aptitude."

(4) Grade point averages used were obtained from the permanent student records at Hudson's Bay High School. The grade points were figured as of the end of the Junior Year Cor, stated differently, as of the beginning of the Senior year). In other words these are the grade point averages of the students before entering either the Cooperative or Office Practice programs.

(5) The students' background in number of business courses taken was also obtained from permanent school records. This figure represents the number of semester hours of credit in business subjects each student had taken through the Junior year or prior to entering the programs.

(6) Office Information and Skills Test. This test was authored by G. Elizabeth Ripka, and published by Houghton Mifflin in 1970. Although the test is in the process of standardization so that information on norms, validity, and reliability is not available, it seemed worthwhile to include it in this study for several reasons. First, since Hudson's Bay High School had been one of the schools to participate in the standardization, a sufficient quantity of tests were available for use at no cost. Second, because of the problems mentioned earlier regarding the late timing of the other "pre-tests," it seemed advisable to use a test 
which could be given very early in the school year. Only Part 1, consisting of ninety true-false and ten multiplechoice questions, was used. (Parts 2 and 3 were a timed typing test and an error correction test.) The test was timed with a limitation of thirty-five minutes.

(7) Timed test of lettex-typing ability. This test has been used by the researcher and a number of other office Practice teachers over a period of several years. It is not a published or standardized test. It is simply the text of a fairly typical business letter. The students were given a period of ten minutes to type the letter (after paper was in their inachines and tabs set), and were instructed that the completed letter should be mailable. The students were scored by first counting the number of words typed in the letter (or letters) they completed during the ten minutes. From this total were subtracted ten words for each "major" error and five words for each "minor" error. These tests were scored by the researcher and "major" errors were defined as spelling errors, punctuation errors, spacing errors, and any other errors which were very noticeable. "Minor" errors were classified as those which many readers might miss, such as sloppy corrections, half-spacing errors, etc. As these critorion are very familiar to the researcher after a number of years! use, it is believed that scoring was consistent. A copy of the test is included in the Appendix.

(8) The Minnesota Clerical Test, 1959 revision, was 
authored by Dorothy M. Andrew and Donald G. Paterson. Reliability and validity data are available in the Manual. Reliability coefficients range from .61 to .93 on various studies listed. There have been many studies of validity. According to Donald E. Super, reviewing the test in Buras, 22 "The treatment of validity in the manual was, in 1946 , unusually good...But reliance is, for today, too heavily on excellent original work... In summary, the Minnesota C1erica1 Test is as good a test as it ever was, and still probably has no effective rival." The test has two sections, each of which gives a separate score, one for name checking and one for number checking. For the purposes of this study, these two scores were averaged, giving a single, composite score for each student on this test.

(9) Short Tests of Clerical Ability. This test was developed by Jean Maier Palormo, and was ptiblished in 1960 by Science Research Associates. The Manual23 indicates that the test-retest reliability coefficients range from .68 to .91. "Concurrent validity data for supervisory ratings are reported for all subtests (except Business Vocabulary and Language) in the form of biserial correlations for office personnel in two manufacturing concerns." 24 These range from .23 to .60 on the various tests. Although the reliability and validity data is less than completely adequate, this test seemed to be the best test available to the general user for measuring a wide range of clerical 
ski11s. For the purpose of this study, after each of the seven test scores (coding, checking, filing, directions, arithmetic, vocabulary, and language) were obtained, these were averaged for each student to obtain a composite score for the total test battery.

(10) Business Judgment Test. This test was authored and published by Martin M. Bruce and copyrighted in 1956. Although reviewers in Buros $^{25}$ indicate that it has weaknesses, it is one of the few available for the purpose of measuring business judgement. It was used in this study to provide" a means of getting some estimate of the less tangible learnings in the business field which could have occurred during the year either in school or in the work experience situations of the Cooperative students. The information in the Manual26 is not conclusive as to validity with some studies showing significant correlations and others in which little or no predictive validity was found. Reliability is good, with a test-retest reliability coefficient of . 81 for a sample of 200 cases.

(11) Minnesota Satisfaction Questionnajre. This questionnaire was developed by Vocational Psychology Research at the Industrial Relations Center, University of Minnesota. The 1967 revision was used. The test was developed as a measure of employee satisfaction with a number of different aspects of their work environment. Reliability of the measure seens satisfactory, with test- 
retest correlations of .61 and .83 and Hoyt reliability coefficients for internal consistency of .80 or above in $83 \%$ of the cases. Reviewers in Buros 27 indicate that there is some evidence of validity, "...mainly in the form of construct validity resulting from attempts to use the MSQ to test various predictions from the theory of Work Adjustment" developed at the University of Minnesota's Industrial Relations Center. For the purposes of this study the questionnaire was scored by counting the number of responses which fell into the "satisfied," "very satisfied," and "extremely satisfied" categories to obtain a percentage of favorable responses which could be compared for each group.

(12) Merit Rating Series--clerical. This test was developed by Joseph E. King and published by Industrial Psychology, Inc. The copyright date was 1955. This instrument is designed to measure job performance on the basis of yes and no answers by the employer to sixty behavior statements. The statements can be scored to indicate performance traits in several categories, such as quantity, accuracy, etc. According to Seymour Levy in Buros $2 \dot{8}$, "There is considerable evidence with respect to ...reliability.... and all the reliabilities appear to be quite satisfactory. Studies reporting satisfactory external validation are recorded for the clerical and for the mechanical scales." Levy concludes that the instruments were developed with "great care." Again with this 
the scoring process was somewhat simplified to allow for easier comparison between the two groups. All of the items about the employee which were positive were counted. Then the percentage relationship between these positive responses and the total was figured to give a single score for each student.

(13) Percentage of Students Employed. This was determined by a follow-up study in which each student was contacted in person or by telephone during the last week of June, 1973, in order to learn her employment status. This allowed the graduates nearly a full month to obtain employment.

\section{STATISTICAL DATA ANALYSIS}

The statistical tool used in this study was the " $t$ " test to determine the significance of the difference between means. The " $t$ " test is based on the assumptions of normal distribution of attributes being measured and of random sampling of a population. The assumption of random sampling cannot specifically be upheld in this research, but the " $t$ " test was determined the most appropriate tool for the circumstances.

The initial procedure of the statistical data processing involved the scoring of the various tests and measures to obtain raw scores.

The raw scores were processed by electronic calculator 
to obtain a mean and a standard deviation for the Cooperative Student group and the office Practice group for each set of measures used.

Next, the standard error of difference was obtained for each test and measure comparing standard deviations by group. Then " $t$ " was obtained by dividing the difference between the group means on each test by the standard error of difference. With this information it was possible to determine the significance of the difference between the two groups.

In order to be considered significant at the .05 level, " $t$ " was required to reach 2.042 , at the .02 level to reach 2.457 , at the .10 level to reach 1.697 and at the .20 level to reach 1.310 on most measures. These levels of " $t$ " were obtained using "Student's" (W.S. Grosset) $t$ Table and allowing 30 degrees of freedom. The formula $D F=N_{1}-1+N_{2}-1$ was used to arrive at the proper figure for degrees of freedom. Group Ns for all but two of the tests were 16-17 and 17-18. Since the " $t$ " tables used do not show a breakdown for degrees of freedom between 30 and 40 , a DF of 30 was felt to yield a sufficiently stable "t". On only two of the measures, Minnesota Satisfaction and Merit Rating Series, did the group size vary from this average. On the Minnesota Satisfaction Questionnaire group sizes were 17 and 12 , yielding a DF of 27. For this measure the required " $t$ " at the .05 
level was 2.052 . On the measures of employer satisfaction, (the Merit Rating Series), group sizes were 16 and 7 , yielding a DF of 21 . The required " $t$ " for the Merit Rating Series was 2.080 .

The first statistical analysis involved the initial comparison of the two groups for equivalency on measures of vocational interest, school motivation, intelligence, grade point average, and number of business courses taken. No significant difference between the two groups was found. It was, therefore, not considered beneficial to apply the statistical technique of analysis of covariance to the final test comparisons.

The next statistical analysis involved comparison of the two groups on the various business and clerical tests given as pre- and post-tests. With the exception of the test of letter-typing skill, no significant differences on pre-test scores was found between the two groups and again, it was not considered beneficial to apply analysis of covariance to the post-test comparisons.

In the case of the test of 1etter-typing skill, a1though a significant difference in favor of the Cooperative group was found on the pre-test, a decision was made not to apply analysis of co-variance. Although this statistical tool would have been appropriate under these circumstances, limitations placed on the researcher made this not practicable. It is felt by the researcher, in view of the small difference between the post-test means of the two groups, 
that even if analysis of covariance had been applied to the post-test, results still would not have reached the significant 1eve 1 . 


\section{CHAPTER V}

\section{ANALYSIS OF FINDINGS \\ I. COMPARATIVE DATA}

Presented in Table I are the data from the initial series of tests used to determine the equivalency of the Cooperative and Office Practice groups. It is important to note that the difference between the two groups was not significant at the .05 leve 1 of probability $( \pm 2.042)$ on any of the tests. On only one test, the School Motivation Analysis Test, did the significance exceed the .10 level of probability $( \pm 1.697)$ with a " $t$ " of 2.03. Also of some interest is the " $t$ " of -1.63 on the Strong Vocational Interest score for the "Secretary" scale; this figure approaches the .10 level of significance, and indicates a possibly higher interest in secretarial work on the part of the Office Practice group.

The data in Table I indicate that the two groups being compared were not significantly different prior to the "treatment." They also indicate that null Hypothesis One ( $\left.\mathrm{Ho}_{1}\right)$ is accepted. There is no significant difference between the scores of the Cooperative Students and the Office Practice students on measures of: vocational interest, school motivation, intelligence, grade point, and number of 
TABLE I

COMPARISON OF RESULTS ON MEASURES USED TO DETERMINE THE INITIAL EQUIVALENCY OF THE TWO GROUPS

\begin{tabular}{|c|c|c|c|c|c|}
\hline $\begin{array}{c}\text { Title of Test } \\
\text { or } \\
\text { Measure }\end{array}$ & $\begin{array}{l}\text { Mean Scores } \\
\text { Cooperative } \\
\text { Group }\end{array}$ & $\begin{array}{c}\text { Mean Scores } \\
\text { Office Practice } \\
\text { Group }\end{array}$ & $\begin{array}{l}\text { Standard Deviation } \\
\text { Cooperative } \\
\text { Group }\end{array}$ & $\begin{array}{c}\text { Standard Deviation } \\
\text { Office Practice } \\
\text { Group }\end{array}$ & "t" \\
\hline $\begin{array}{l}\text { Strong Vocational } \\
\text { Interest--Women } \\
\text { Office Practice }\end{array}$ & 60.25 & 61.76 & 9.685 & 6.933 & .51 \\
\hline $\begin{array}{l}\text { Strong Vocational } \\
\text { Interest--Women } \\
\text { Secretary }\end{array}$ & 51.56 & 56.29 & 10.072 & 5.871 & -1.63 \\
\hline $\begin{array}{l}\text { School Motivation } \\
\text { Analysis Test }\end{array}$ & 123.78 & 119.24 & 7.059 & 6.159 & $2.03^{* *}$ \\
\hline $\begin{array}{l}\text { Otis-Lennon } \\
\text { Mental Ability }\end{array}$ & 101.00 & 100.29 & 10.959 & $8.879^{\circ}$ & $.2 \mathrm{I}$ \\
\hline Grade Point Average & 3.08 & 2.84 & .583 & .447 & 1.20 \\
\hline $\begin{array}{l}\text { Business Courses Taken } \\
\text { to Senior Year }\end{array}$ & 5.89 & 5.59 & 2.297 & 1.805 & .43 \\
\hline
\end{tabular}


business courses taken.

The next analysis concerned the several measures of clerical skill which were used both as pre- and post-tests. The result of the processing of these test scores is shown in Table II. It is again important to note that on only one of the clerical skills tests given as pre-tests was there a significant difference between groups, or any " $t$ " approaching significance on any test. The "t" of 2.62 on the letter-typing pre-test does indicate a significant difference between groups on this pre-test, with the Cooperative Students performing much better than the Office Practice students. The mean score of the Cooperative Students was 11.21 , while that of the Office Practice students was 5.44. This relatively large initial difference between groups made it more difficult for the Cooperative group to show as large a gain on the post-test of letter-typing skil1, as did the Office-Practice group.

On only one of the tests, the Minnesota Clerical, was there a significant difference between groups on the post test. On this test the " $t$ " of 2.30 is significant at the .05 level of probability. It is also of some interest that on the Short Tests of Clerical Ability, the "t" of 1.78 is significant at the .10 level for the post test.

The data in Table II warrant the acceptance of null Hypotheses two and five $\left(\mathrm{Ho}_{2}, \mathrm{Ho}_{5}\right)$ for both the pre-tests and the post-tests. Null Hypotheses four $\left(\mathrm{Ho}_{4}\right)$ is accepted for the pre-test, but is rejected for the post-test because 
TABLE I I

COMPARISON OF RESULTS ON CLERICAL. SKILLS TESTS

USED FOR PRE- AND POST-TESTING

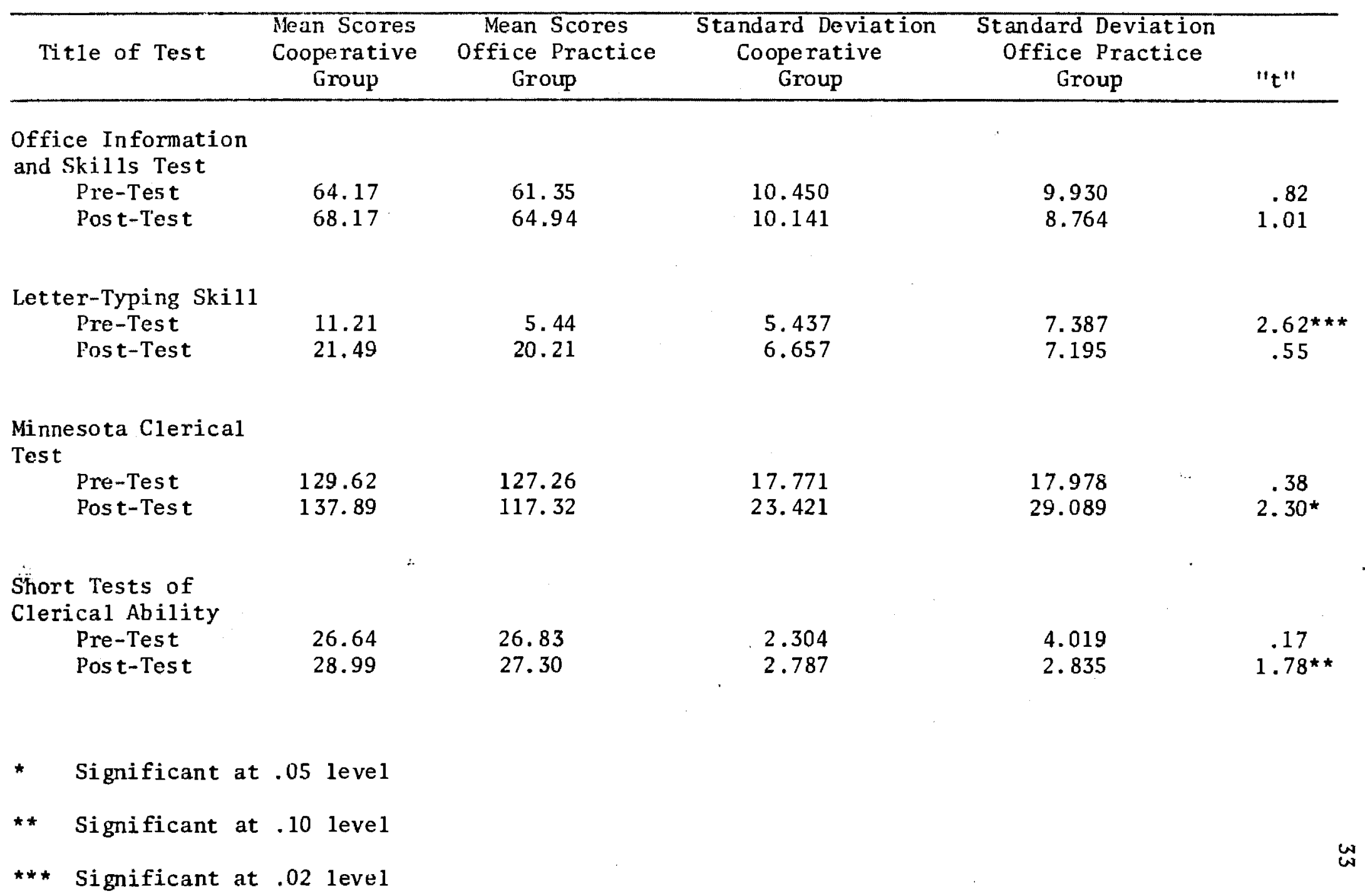


the statistical " $t$ " of 2.30 exceeds the critical value of 2.042 at the .05 level of significance. Nu11 Hypothes is three $\left(\mathrm{Ho}_{3}\right)$ is accepted for the post-test, but is rejected for the pre-test because the statistical " $t$ " of 2.62 exceeds the critical value of 2.042 at the .05 level of significance.

Presented in Table III are the data for the final measures used to compare the two groups. These measures were the test of business judgment, the test of employee satisfaction (Minnesota Satisfaction Questionnaire), and the measure of employer satisfaction (Merit Rating Series--Clerical).

As the table indicates there was no significant difference between the two groups on the Business Judgment Test. The " $t$ " for this test was 1.40 , which is significant on $1 y$ at the . 20 level of probability $( \pm 1.310)$. Thus null Hypothesis six $\left(\mathrm{Ho}_{6}\right)$ is accepted.

On the measures of employee satisfaction and employer satisfaction there is, as Table III indicates, no significant difference between the Cooperative and Office Practice groups when the means and the " $t$ " test are computed using an " $N$ " which represents only the members of each group who are employed and by whom the measures were prepared. On this basis, nul 1 Hypotheses seven $\left(\mathrm{Ho}_{7}\right)$ and eight ( $\mathrm{Ho}_{8}$ are accepted.

In Table IV is found the information which appears to show the largest differences between the two groups at the end of their training. It should be noted that the Cooperative group is $94 \%$ employed, compared to $65 \%$ for the 
TABLE I I I

COMPARISON OF RESULTS ON FINAL MEASURES USED TO TEST BUS INESS JUDGMENT AND TO DETERMINE THE EXTENT

OF EMPLOYER AND EMPLOYEE SATISFACTION

\begin{tabular}{lcccc}
\hline $\begin{array}{l}\text { Title of Test } \\
\text { or } \\
\text { Measure }\end{array}$ & $\begin{array}{c}\text { Mean Scores } \\
\text { Cooperative } \\
\text { Group }\end{array}$ & $\begin{array}{c}\text { Mean Scores } \\
\text { Office Practice } \\
\text { Group }\end{array}$ & $\begin{array}{c}\text { Standard Deviation } \\
\text { Cooperative } \\
\text { Group }\end{array}$ & $\begin{array}{c}\text { Standard Deviation } \\
\text { Office Practice } \\
\text { Group }\end{array}$ \\
\hline $\begin{array}{l}\text { Business Judgment } \\
\text { Test }\end{array}$ & 55.17 & 52.59 & 6.592 & 6.215 \\
"t"
\end{tabular}


A COMPARISON OF THE EMPLOYMENT STATUS OF

THE COOPERATIVE AND OFFICE PRACTICE

GROUPS, JUNE, 1973

\begin{tabular}{|c|c|c|}
\hline $\begin{array}{l}\text { Type of } \\
\text { Employment }\end{array}$ & $\begin{array}{c}\text { Number of } \\
\text { operative Students } \\
\text { Employed } \\
\text { Tota1 Group }=18\end{array}$ & $\begin{array}{c}\text { Number of } \\
\text { Office Practice } \\
\text { Students Employed } \\
\text { Total Group }=17\end{array}$ \\
\hline Data Entry & 7 & $4 *$ \\
\hline Doctor's Office & 2 & - \\
\hline Escrow/Real Estate & 2 & - \\
\hline Bank & 1 & - \\
\hline Federa1-Bonneville Power & 2 & - \\
\hline Beauty Shop--Bookkeeper & 1 & - \\
\hline School District & $1 *$ * & - \\
\hline Contractor's office & 1 & - \\
\hline TOTAL EMPLOYED "OFF ICE" WORK & 17 & 4 \\
\hline Retail & - & 3 \\
\hline Waitress & - & 3 \\
\hline Nurse's Helper & - & 2 \\
\hline TOTAL EMPLOYED NON-OFFICE & 0 & 8 \\
\hline TOTAL EMPLOYED & 17 & 12 \\
\hline TOTAL UNEMPLOYED & 1 & 5 \\
\hline PERCENTAGE EMPLOYED & $94 \%$ & $65 \%$ \\
\hline $\begin{array}{l}\text { PERCENTAGE EMPLOYED IN OFFICE } \\
\text { WORK S ITUATIONS }\end{array}$ & $94 \%$ & $24 \%$ \\
\hline \multicolumn{3}{|c|}{$\begin{array}{l}\text { * Of these four, three were employed after graduation by a Cooperative } \\
\text { Employer. }\end{array}$} \\
\hline \multicolumn{3}{|c|}{$\begin{array}{l}\text { * Although this student was working at the time the data was gathered, } \\
\text { her position will not continue. If she is considered "unemployed", } \\
\text { the Percentage Employed for the Cooperative Group would be only } 89 \%\end{array}$} \\
\hline
\end{tabular}


Office Practice group. Even more important is the fact that while $94 \%$ of the Cooperative group are employed in the business and office area of their vocational training, only $24 \%$ of the Office Practice students are so employed. Of that 24\% three students of the Office Practice group are employed by a Cooperative Employer who hired them after graduation. On the basis of the data in Table IV, null Hypothesis nine $\left(\mathrm{Ho}_{9}\right)$ is rejected. 


\section{$\therefore$ II. SUMMARY OF MAJOR FINDINGS}

1) There was no statistically significant difference between Cooperative students and office Practice students on initial tests and measures of vocational interest, school motivation, intelligence, grade point, and business course background.

2) There was no statistically significant difference between Cooperative students and office Practice students on the following "pre-tests": Office Information and Skills Test, Minnesota Clerical Test and the Short Tests of Clerical Ability.

There was a statistically significant difference in favor of the Cooperative group on the pre-test of lettertyping skill.

(3) There was no statistically significant difference between Cooperative and Office Practice students on "posttests" of Office Information and skills, letter-typing skill and the Short Tests of Clerical Ability.

There was a statistically significant difference in favor of the Cooperative group on the Minnesota Clerical Test used as a post-test.

(4) There was no statistically significant difference between Cooperative and Office Practice groups on the final measures of; business judgment, employee satisfaction, and employer satisfaction. 
(5) There was a 1 arge difference between office Practice and Cooperative students in employment status. Cooperative students showed a much higher percentage of employment and of employment in clerical and office situations.

\section{CONCLUSIONS AND RECOMMENDATIONS}

The conclusions and recommendations which follow are those drawn from the findings of this study. It is recognized that the study has a number of limitations, and it is hoped that, rather than being considered difinitive, it will provide impetus, background, and information which will be helpful in carrying on further research to determine the relative effectiveness of Cooperative Business Education.

Because of the lack of significant differences between Cooperative and Office Practice students on all of the initial measures and on all but one of the pre-tests of clerical skills, one can conclude that enough similarity between the groups exists at the beginning of the senior year to warrant further studies to determine the effects of the different training received by the two groups.

If replication of the study were planned, it is the belief of the researcher that the initial testing for equivalency of groups could be somewhat simplified. Recommended would be the retention of the otis-Lennon Mental Ability Test, the comparisons of grade point and business course background, and the "Office Practice" Scale of the Strong Vocational Interest Blank. However, after the more careful 
study of tests and test manuals possible during the course of this study, it" is believed that the "Secretary" scale comparison of the Strong Test could be omitted since as the Strong 29 Manual itself suggests, "...the emphasis...in this age range should be on...the general direction of a career" and the "Office Practice" scale gives the necessary general direction. It is also suggested that use of the School Motivation Analysis Test be omitted. Careful study of the SMAT 30 manual makes it questionable whether this test provides any more accurate a measure of motivation in school than does the grade point average.

The results of the study indicate that on many measures of clerical skill there is no significant difference between the end-of-year performance of Cocperative and Office Practice Students. In general there is more difference between groups on post-tests than on pre-tests however, with the Cooperative group means from one-and-a-quarter to twenty points higher than those of the Office Practice group. The results did indicate a significant difference between groups on one of the clerical post-test scores--that of the Minnesota Clerical Test.

Although the reasons for the lack of significant differences between the two groups on all of the clerical posttest scores but one are not known, a number of possible causes suggest themselves to the researcher. First, the timing of the post-tests was not ideal. The majority of 
the post-testing was done on the last two days of attendance for seniors. A number of the students in both groups had been "partying" and engaging in a number of other exuberant senior "flings." It seems to the researcher that this could have resulted in poorer performance for both groups, and also in a tendency for the Cooperative group and the Office Practice group to obtain scores more similar than different. Much of the recently gained learning from the on-the-job experiences of the Cooperative group may not have been utilized in testing under those circumstances. Contributing to this effect also is the fact that the students had originally been told that scores on the tests for the research study would have no effect on their grades, so that especially on these last days of school they may not have put forth their best efforts.

Another possible reason for the failure to find significant differences on the majority of post-tests, may have had to do with the nature of the tests themselves. The one significant difference was found on the Minnesota Clerical Tests which, of all the tests used, is the most thoroughly tested and validated. The researcher's original choice for the other standardized clerical test had been the Short Employment Tests (Bennett and Gelink) which testing experts in Buros 31 indicate to be a very sound test. However, it was found that this test is available only to businesses, so the less thoroughly researched Short Tests of Clerical Ability was used. In a replication of the study it is 
recommended that the clerical tests available on the market be carefully re-studied to determine which, in addition to the Minnesota Clerical, will give the most accurate results. If it is again determined that the Bennett and Gelink tests are preferable, a special effort to get the publisher to release them for use in this research should be made. For future replication it is also suggested that a standardized test of typing skill be used, and that the office Information and Skills: Test be replaced by a similar standardized test. With these changes, it is stil1, of course, possible that no significant differences between groups will be found on the post-tests, but greater confidence could be placed on the results in that case.

Another theory which might explain the significant posttest result on the Minnesota test is that since it is designed to be a test of speed and accuracy, it is possible that the on-the-job experience received by the Cooperative Students was an important factor in helping them to become faster and more accurate. The other clerical tests (except the letter-typing test) were more general in character and the varied work experiences of the Cooperative group may not have been as helpful to them in increasing general information as was the classroom experience received equally by both groups. Perhaps none of the tests used is a completely adequate measure of the kinds of changes produced in students by the cooperative work experience and an attempt should be made to add another test which will more accurately reflect 
those changes.

Although no significant difference was found on the test of letter-typing skill, reasons for this have already been explained. The much poorer showing of the office Practice Students on the pre-test made it much more difficult for the Cooperative Students to show as large a gain. Also, it is agreed by business teachers that, after a high level of performance has been reached in typing speed and accuracy, additional gains become increasingly difficult. This is true of skill development in many fields, and may account, at least in part, for the lack of a significant difference on that post-test.

This same factor of the increasing difficulty of continuing gains in skill learnings may be a reason for considering, in a replication of this study, the wisdom of the decision to use raw scores rather than percentiles. Perhaps percentiles rather than raw scores would have given a fairer picture of the gains made by the students in the course of the year.

The final measures compared in the study also failed to show significant differences between the two groups. The difference on the test of Business Judgment, significantly only at the .20 level, may either reflect a genuine 1 ack of difference or the inability of this particular test to measure it. Although it was the only test found by the researcher to measure such intangible learnings, there is 
little to convince one that it is a thoroughly accurate measure.

There was also little significant difference in the measures of satisfaction of employers and employees, and again a number of possible reasons for this. The office Practice Students, in genera1, were evaluated in positions which were somewhat less demanding than those of the Cooperative Students. Also, the Cooperative Employers had been "trained" to make critical evaluations of the Cooperative Employees during the course of the time during which they participated in the program. It is a1so possible that a more accurate evaluation by employers could be obtained by using a scale with more choices than "yes" or "no." With regard to employee satisfaction, it is possible that the already experienced and employed Cooperative Students have set higher goals for their work situations than the office Practice students whose jobs are more temporary in nature. Certainly, the low number of employer respondents in the Office Practice group had a considerable effect on the results. If the means and the " $t$ " test for employer satisfaction had been computed on the basis of the total group (including those not employed and not responding) the results would have been considerably altered, with the difference between groups highly significant in favor of the Cooperative Students. Although this method was not used, it seems to have some logical validity, since a student who is unemployed or whose employer refuses to prepare a 
five-minute rating scale can certainly be considered to be a less than satisfactory employee. In other words, the lack of complete data for the Office Practice group makes the lack of significant differences between groups of very questionable importance. In a replication of the study it is recommended that sufficient time be allowed so that measures of employer and employee satisfaction can be obtained for a higher percentage of the sample.

Certainly the most important finding regarding the difference between the two groups was the much higher employment rate of the Cooperative students as well as their higher rate of employment in the clerical and office field. Despite the lack of significant results on many of the other tests and measures used, this one difference would seem to provide a very valid reason for the continuance of Cooperative Office Education programs. It is often with very great difficulty that recent high school graduates find employment. The $94 \%$ employment rate of the Cooperative students as compared to the $65 \%$ employment of the Office Practice Students seems a very important difference between the groups indeed. In addition the comparative figures of $94 \%$ and $24 \%$ for employment in clerical-office positions indicates that the Cooperative Program is much more effective in achieving the goal of occupational competency correlated with employment possibilities. It should be noted that the difference in employment status of the two groups may be related to factors not considered in this study. The Hawthorne effect may be 
operating to cause more favorable attitudes in the Cooperative Students.

Another possible factor related to the much higher employment rate of the Cooperative Students is inherent in the different treatment of the two groups. Perhaps the additional experiences and attention provided the Cooperative Students both by the teacher and the employer resulted in the development of an improved self-concept. Although the nature of the two programs made it impractical to attempt to control this effect, it should be recognized that development of a more positive self-concept may in itself explain the apparently greater employability of the Cooperative Students.

A longer term follow-up of this group would yield interesting information on the extent to which the employment percentages would vary with the passage of time. It is the hope of the researcher that such a follow-up will be possible to carry out over the next eighteen month to two year period. In any case it is highly recommended that any future replications of the study include a follow-up period of approximately two years, and if possible, a research design which allows greater control of variables.

Many of the recommendations suggested by the findings and conclusions of this study have already been mentioned, however a number of these should be re-emphasized and certain additional recommendations added. The most important of these is the recommendation that the study be replicated 
with the several changes and additions which seem indicated both by the results of the study and by the information gained in the course of obtaining the data. Any replication should be based upon a larger sample including Cooperative and Office Practice students from several schools. It should also utilize the longer follow-up period of eighteen months to two years which was previously mentioned. The first follow-up should occur no earlier than two months after graduation, and"preferably during the following September. The test schedule should be improved, with all pre-tests administered during the first month of school and the posttests administered at 1 east three weeks before the end of school.

It is the strong feeling of the researcher that further research to determine the comparative effectiveness of Cooperative Business Education is needed. Although the findings of this study are recognized as being highly tentative, it is hoped that the information gained will be of assistance in designing future research on this subject, as well as in providing at least some comparative information on the effectiveness of Cooperative Business Education. 


\section{REFERENCES}

1. Chase, Edward T. 1964. "Learning to be Employable," Harper's Magazine, May, 35-42.

2. Educational Resources Information Center 1966-1972. Research in Education. (ERIC) All volumes of abstracts and indexes. U.S. Department of Health Education and Welfare/National Institute of Education.

3. The Center for Vocational and Technical Education 19671971. Abstracts of Research and Related Materials in Vocational and Technical Education. (ARM) Al1 volumes of abstracts and indexes. Ohio State University, Columbus, Ohio.

4. Army Missile Command, Redstone Arsenal, Alabama 1970. "A Study of the Effectiveness of a Cooperative Education." (ERIC Microfiche, ED 060223).

5. Ryan, LaVerne 1969. "A Comparative Study of Vocational Cooperative and Simulated Business and Office Programs" Murray State University, Kentucky. Abstract only available, Abstracts of Research Materials in Vocational and Technical Education, Fall 1971, 32 .

6. Ferguson, Edward T. Jr. 1969. "A Comparison of the Effectiveness of the Project and Cooperative Methods of Instruction on Selected Competencies in Distributive Education at the Secondary Level," Michigan State University, (ERIC Microfiche, ED 020419).

7. Miller, Clarence Melvin 1968. "An Experiment Designed to Determine the Holding Power for a Work Experience for Students Classified as Potential Dropouts," Colorado State College, Greeley, Colorado, $180 \mathrm{pp}$. Microfilm No. 69-2860.21. cf Price, Ray G., Hopkins, Chas . R. 1970, April. "Review and Synthes is of Research in Business and Office Education," Ohio State University, Columbus, Ohio, 28-29, (ERIC Microfiche, ED 038520).

8. Hodge, James Leslie 1968. "Cooperative Office Education and its Effect on Attitudes Toward Office Employment," Arizona State University, Tempe, Arizona, $136 \mathrm{pp}$. Microfilm No. 68-14999.30. cf Price, Ray G., Hopkins, Chas. R. 1970, April. "Review and Synthesis of Research in Business and Office Education," Ohio State University, Columbus, Ohio, 30, (ERIC Microfiche, ED 038520 ). 
9. Rothwe11, Wade B. and Baker, Richard R. 1970. "Re1ationship of Proficiency Ratings and Personality Traits to Job Success of Stenographic and Secretarial Science Graduates," Auburn University. Alabama. (ERIC Microfiche, ED 052389 ).

10. Lee, Charlotte A. 1966. "A Study of Cooperative office Education Programs in the State of Illinois to Determine the Nature and Extent to Which Such Programs Serve the Needs of Low and Average Ability Students," Northern Illinois University, DeKa1b, I1linois, cf Price, Ray G., Hopkins, Chas. R. 1970, April. "Review and Synthesis of Research in Business and Office Education, Ohio State University, Columbus, Ohio, 31, (ERIC Microfiche, ED 038520).

11. Lewis, Jewe11 Lorene 1966. "A Survey of High School Cooperative Education Programs in Missouri, Oklahoma, Kansas, and Arkansas," Kansas State College of Pittsburg, Pittsburg, Kansas, 59 pp., cf Price, Ray G., Hopkins, Chas. R. 1970, April. "Review and Syntheses of Research in Business and Office Education, Ohio State University, Columbus, Ohio, 31, (ERIC Microfiche, ED 038520 ).

12. Shultz, Kenneth 1961. "A Study of Cooperative WorkExperience Programs in a Selected Group of Secondary Schools of the State of Pennsylvania for 1957-58," Témple University, Philadelphia, Pennsylvania, 385 pp., Microfilm No. 61-4065, cf Lanham, Frank W. and Trytten, J.M. 1966, August. "Review and Synthesis of Research in Business and Office Education, Ohio State University, Columbus, Ohio, Center for Vocational and Technical Education, $144 \mathrm{pp}$, (ERIC Microfiche, ED $011566)$.

13. Cook, Fred, and Lanham, Frank 1966. "Opportunities and Requirements for Initial Employment of School Leavers with Emphasis on Office and Retail Jobs," Wayne State University, Detroit, Michigan, cf Lanhan, Frank W. and Trytten, J.M. 1966, August. "Review and Synthesis of Research in Business and Office Education, Ohio State University, Columbus, Ohio, Center for Vocational and Technical Education, $144 \mathrm{pp}$, (ERIC Microfiche, ED 011566).

14. Sanders, Lester E. 1967. "A Comparison of Two Methods of Preparing Youth for Employment, Cooperative Occupational Education Versus the Preparatory VocationalTechnical School," University of Missouri, Columbia, Missouri, 26 pp., (ERIC Microfiche, ED 050226). 
15. Campbel1, David P. 1969. Strong Vocational Interest Blank Manual 2969 Supplement For Men's Form T39g and Women's Form T398, Stanford, California, Stanford University Press, p. 21.

16. Ibid.

17. Strong, Edward K. Jr. revised by Campbe11, David P. 1959 and 1966. Strong Vocational Interest Blanks Manual, Stanford, California, Stanford University Press, p. 45.

18. Buros, Oscar K. editor 1972. The Seventh Mental Measurements Yearbook, Voluine II, New Jersey, The Gryphon Press, p. 319, Test 135.

19. Ibid. p. 690, Test 370 .

20. Otis, Arthur S, and Lennon, Roger T. 1967. OtisLennon Mental Ability Test Manual for Administration Elementary II, Intermediate, and Advanced Levels, New York, Harcourt, Brace and World, Inc:

21. Buros, op. cit., p. 691, Test 370 .

22. Buros, Oscar K. edition 1959. The Fifth Mental Measurements Yearbook, New Jersey, The Gryphon Press, p. 872 , Test 850 .

23. Palormo, Jean Maier 1960. Manual for SRA Short Tests of Clerical Ability Preliminary Edition, Chicago, Illinois, Science Research Associates, Inc.

24. Buros, Oscar K., editor 1965. The Sixth Mental Measurements Yearbook. New Jersey, The Gryphon Press, p. 1265 , Test 1046 .

25. Buros, op. cit. Seventh Yearbook, Vol. I. p. 1488, Test 1057 .

26. Bruce, Martin M. 1965. Examiner's Manual Business Judgment Test, Revised, New Rochelle, New York.

27. Buros, op. cit. Seventh Yearbook, p. 1492, Test 1064.

28. Ibid. p. 1334 , Test 1123 .

29. Strong, 1oc. cit.

30. Sweney, Arthur B., Catte11, Raymond B., and Drug, Samue 1961 and 1970 . Manual for the School Motivation Analysis Test, Champaign, Illinois, Institute for Personality and Ability Testing. 
31. Buros, op. cit. Sixth Yearbook, pp. 1263-65, Test 1045. 


\section{BIBLIOGRAPHY}

The Center for Vocational and Technical Education 1967-1971. Abstracts of Research and Related Materials in Vocational and Technical Education. (ARM) A11 volumes of abstracts and indexes. Ohio State University, Columbus, Ohio.

Ebel, Robert L. editor, 1969. Encyclopedia of Educational Research, New York, MacMillan Co., (American Educational Research Assn.), "Vocational and Technical Education," pp. 1506-1522, and "Business Education," pp. 105-116.

Ehrenreich, Julia W., Education Index, Volumes XIX, XX, XXI.

Helmstadter, G. C. 1970. Research Concepts in Human Behavior, New York, Appleton-Century-Crofts.

Lanham, Frank W. and Trytten, J.M. 1966, August. Review and Synthesis of Research in Business and Office Education, Ohio State University, Columbus, Ohio, Center for Vocational and Technical Education, $144 \mathrm{pp}$. (ERIC Microfiche, ED 011566).

McCa11, Robert B. 1970. Fundamental Statistics for Fsychology, New York, Harcourt, Brace and World, Inc.

Price, Ray G., Hopkins, Chas. R. 1970, Apri1.. Review and Synthesis of Research in Business and Office Education, Ohio State University, Columbus, Ohio, (ERIC Microfiche, ED 038520 ).

Smith, Patricia, Kenda11 L., Hulin, Charles 1969. The Measurement of Satisfaction in Work and Retirement, $A$ Strategy for the Study of Attitudes. Chicago, Illinois, Rand McNa1ly \& Co. 


\section{APPENDIX}

TYPING PRE-TEST

\section{DIRECTIONS :}

You will have 10 minutes to complete the pre-test. You will have 2 minutes to get materials organized before the test. You are to try and complete the letter with accuracy and speed and in the best possible form. The letter is to be mailable. Start again if you have sufficient time.

1. LETTER \& ENVELOPE (Choose any style letter you prefer.)

Date/Dr: Willhite Bonnice/School of Business/Wayne State University/Detroit, Michigan 48212/Dear Doctor Bonnice:

I do not know how to thank you enough for all the kindnesses you have extended to me in recent days. I am grateful to you for the gracious way in which you and Mrs. Bonnice led our reception, for your fine help in explaining the research that underlies your filmstrip series, and especially for the way you took Mr. Graham under your wing.

Then, returning to my desk today after the trip to the Safety Council convention, I find that already you have produced the magazine article for which I asked! I have read the material and think highly of it; I am sure that the editor of our publication will be as appreciative of it as 
I am.

Let me say once more how grateful I am for all your courtesies and how much I admire the work you have done. I do not know how you can get so much done, but I am certainly glad you do it!/Cordially yours,/Irwin S. Johnson/ District Sales Manager/Initials/ 